\title{
Lusioersily
}

\section{Solar photocatalytic disinfection of agricultural pathogenic fungi ( Curvularia sp.) in real urban wastewater}

Aguas, Y., Hincapie, M., Fernandez lbanez, P., \& Polo-López, M. I. (2017). Solar photocatalytic disinfection of agricultural pathogenic fungi ( Curvularia sp.) in real urban wastewater. Science of the Total Environment, 60760, 1213-1224. https://doi.org/10.1016/j.scitotenv.2017.07.085

Link to publication record in Ulster University Research Portal

\section{Published in:}

Science of the Total Environment

\section{Publication Status:}

Published online: 11/07/2017

DOI:

10.1016/j.scitotenv.2017.07.085

\section{Document Version}

Author Accepted version

\section{General rights}

Copyright for the publications made accessible via Ulster University's Research Portal is retained by the author(s) and / or other copyright owners and it is a condition of accessing these publications that users recognise and abide by the legal requirements associated with these rights.

\section{Take down policy}

The Research Portal is Ulster University's institutional repository that provides access to Ulster's research outputs. Every effort has been made to ensure that content in the Research Portal does not infringe any person's rights, or applicable UK laws. If you discover content in the Research Portal that you believe breaches copyright or violates any law, please contact pure-support@ulster.ac.uk. 


\section{Reply all $\mid \vee$ 㿻 Delete Junk $\mid \vee \quad \cdots$
Your Submission}

\section{publications}

Ms. Ref. No.: STOTEN-D-17-03731R1

Title: Solar photocatalytic disinfection of agricultural pathogenic fungi (Curvularia sp.) in real urban wastewater Journal: Science of the Total Environment

Hola Inma

I am pleased to inform you that your paper "Solar photocatalytic disinfection of agricultural pathogenic fungi (Curvularia sp.) in real urban wastewater" has been accepted for publication in STOTEN and forwarded to the publishers.

When your paper is published on ScienceDirect, you want to make sure it gets the attention it deserves. To help you get your message across, Elsevier has developed a new, free service called AudioSlides: brief, webcast-style presentations that are shown (publicly available) next to your published article. This format gives you the opportunity to explain your research in your own words and attract interest. You will receive an invitation email to create an AudioSlides presentation shortly. For more information and examples, please visit http://www.elsevier.com/audioslides.

Why not submit your tailored methods to MethodsX? The new open access journal publishes the tweaks you make to methods without the article padding, so you can get the credit for the time and effort you have put into making a method work for you. www.elsevier.com/locate/methodsX

Your accepted manuscript will now be transferred to our production department and work will begin on creation of the proof. If we need any additional information to create the proof, we will let you know. If not, you will be contacted again in the next few days with a request to approve the proof and to complete a number of online forms that are required for publication.

For any production related questions, including changes to proofs, please contact Jennifer Miranda(Journal Manager) J.Miranda@elsevier.com. There is no need to contact the editors.

Thank you for giving us the opportunity to review your article.

Sincerely, y muchos saludos

DAMIA BARCELO

Co Editor-in-Chief

Science of the Total Environment

Comments from the Editor:

For further assistance, please visit our customer support site at http://help.elsevier.com/app/answers/list/p/7923. Here you can search for solutions on a range of topics, find answers to frequently asked questions and learn more about EES via interactive tutorials. You will also find our $24 / 7$ support contact details should you need any further assistance 
